\title{
Theological-mythological viewpoints on divine sonship in Genesis 6 and Psalm $2^{1}$
}

E O Usue

(University of Pretoria)

\section{ABSTRACT}

Theological-mythological viewpoints on divine sonship in Genesis 6 and Psalm 2

This article describes theological and mythological scholarly viewpoints concerning the motif of divine sonship in Genesis 6:1-9 and Psalm 2:1-12. The author, admitting the complex and problematic nature of the inquiry, discusses some of the popular interpretations of both texts and attempts to discern the pros and cons of each reading. Ultimately he points out certain similarities and differences between the two texts. He contends that the motif of divine sonship in Genesis 6 differs in a certain sense from that of Psalm 2. One of the reasons for this difference is that the eschatological expectation of the reign of the Son of God seems to lie behind the text of Psalm 2, whereas, in Genesis 6, it does not.

\section{INTRODUCTION}

Genesis 6 and Psalm 2 are among a list of several Biblical texts with which scholars have struggled with - with regard to ascertaining their genre and explicating their meaning (cf Walton 2001:291; Buttrick 1952:533; Keck 1994:382). Should these Biblical texts be considered as mythology ${ }^{2}$, saga $^{3}$ or history? Or should such texts be

1 This article was read at the Pro-Psalms conference held at the University of Pretoria on August $25^{\text {th }}$ and $26^{\text {th }} 2005$. Dr Usue is a research fellow of the Department of Old Testament Studies, Faculty of Theology, University of Pretoria.

2 Myth describes the "things that occur outside historical time and space, and which only coincide with history during the cultic repetition of the primal event" (Otzen 1980:58). Myth "is the spoken part of ritual" (Gottlieb 1980:63). Myth is "a narrative (story) concerning fundamental symbols that are constitutive of, or paradigmatic for, human existence" (Batto 1992:11).

3 Saga "is rooted in history and gives at least the impression of being a historical narrative" (Otzen 1980:58). Coats (1983:319) understands saga to be "a long, prose, traditional narrative having an episodic structure developed around stereotyped themes or objects... The episodes narrate deeds or virtues 
seen as theological/religious narratives? The problem of defining the term 'mythology' or 'saga' also comes to the fore when one attempts to compare such texts with the ancient Near Eastern myths/sagas that bear resemblances to these biblical texts (see the definition of these terms in footnotes 2-3). Therefore, how does one interpret the Biblical texts that contain allusions to the ANE myths/sagas? And how will that interpretation affect the Reformed Christian conviction about biblical inerrancy, inspiration, authority, perspicuity and authenticity?

The above questions are very crucial and require a thorough reflection when dealing with such texts. But the objective of this article is not to provide an exhaustive discussion or final answers to such questions. Rather, the interest is to describe some scholarly viewpoints on the motif of divine sonship in Genesis 6 and Psalm 2. The article also examines the differences and similarities between the two texts. The hypothesis put forward is that the motif of the eschatological reign of the son of Yahweh lay behind the text of Psalm 2 - a motif that distinguishes it from Genesis 6 where the concept of eschatology is simply absent.

\section{TRANSLATION OF GENESIS 6:1-9}

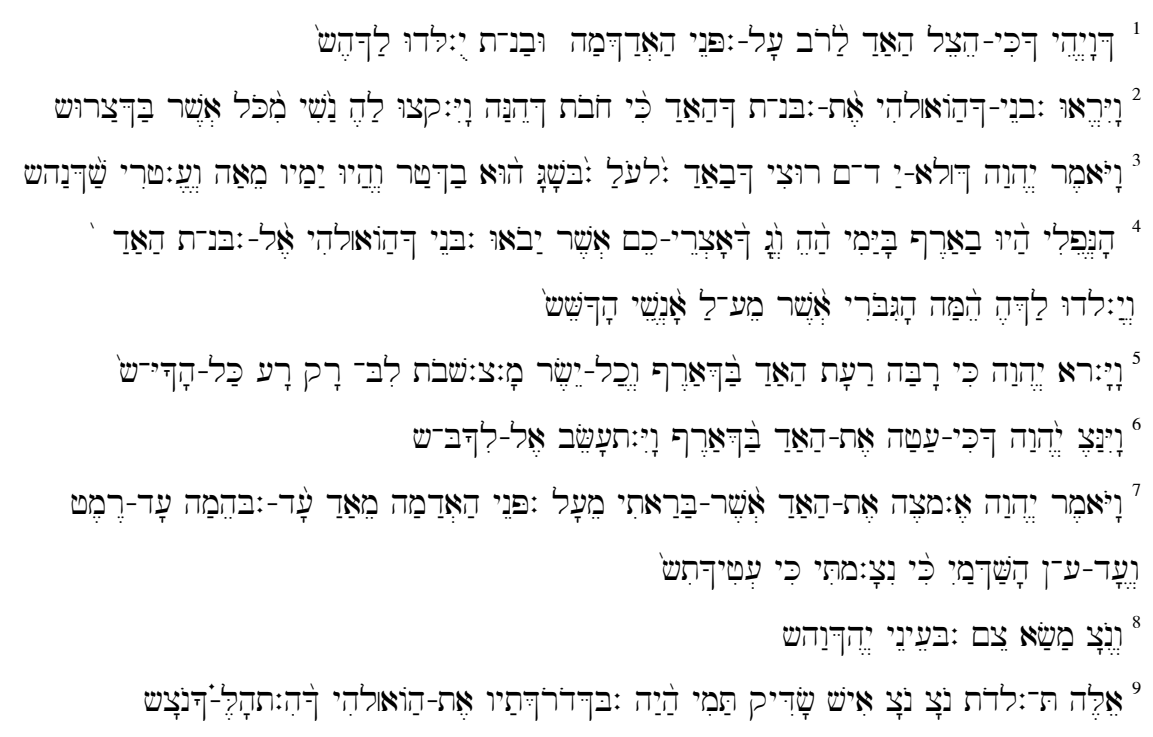

1. And it came to pass that mankind began to increase upon the face of the ground. So, daughters were born to them.

from the past insofar as they contribute to the composition of the present narrator's word". 
2. Then the sons of God saw the daughters of humankind that they were good. So, they took for themselves wives from all whomsoever they chose.

3. Then Yahweh said, "My Spirit shall not judge in mankind forever some which he is flesh also. Now his years shall become a hundred and twenty years.

4. The Nephilim were on earth in those days and also afterwards, when the sons of God went to the daughters of mankind and they bore children to them. They were mighty men who were from ancient. Men of the name.

5. When God saw that there was much evil of the mankind of the earth, and all the form of the thoughts of his heart was only evil all the time.

6. Then, Yahweh regretted that He has made humankind on earth. Thus, He was greatly grieved to His heart.

7. So, Yahweh said, "I will wipe out the mankind which I have created from upon the face of the ground, from mankind as far as beast as far as creeping organism and as far as bird of the heavens because I have regretted that I have made them."

8. But Noah found favour in the eyes of Yahweh.

9. These are the descendants of Noah. Noah was a righteous man. $\mathrm{He}$ was complete in his generation. With God Noah walked.

\section{STRUCTURAL OUTLINE OF GENESIS 6:1-9}

\subsection{Humankind $(6: 1,2,4,5)$}

a. They increased in number (v. 1a)

b. They bore daughters (v. 1b)

c. Sons of God married daughters of humankind (v. 2)

d. Sons of God and daughters of men bore the Nephilim (v. 4a)

e. The Nephilim were mighty and renowned (v. 4b)

f. Humankind and their thoughts were evil all the time (v. 5).

\subsection{Yahweh $(6: 3,6,7)$}

a. Yahweh limits the activity of His Spirit in humankind (v. 3a)

b. Yahweh reduced the life span of humankind down to 120 years (v. 3b) 
c. Yahweh grieved and He regretted/repented that He had made humankind (v. 6, 7b)

d. Yahweh resolved to wipe out humankind and other creatures from the earth (v. 7a).

\subsection{Noah $(6: 8,9)$}

a. Noah found favor/grace in Yahweh's eyes (v. 8)

b. Noah was righteous and perfect; he walked with God (v. 9).

4 TRANSLATION OF PSALM 2:1-12

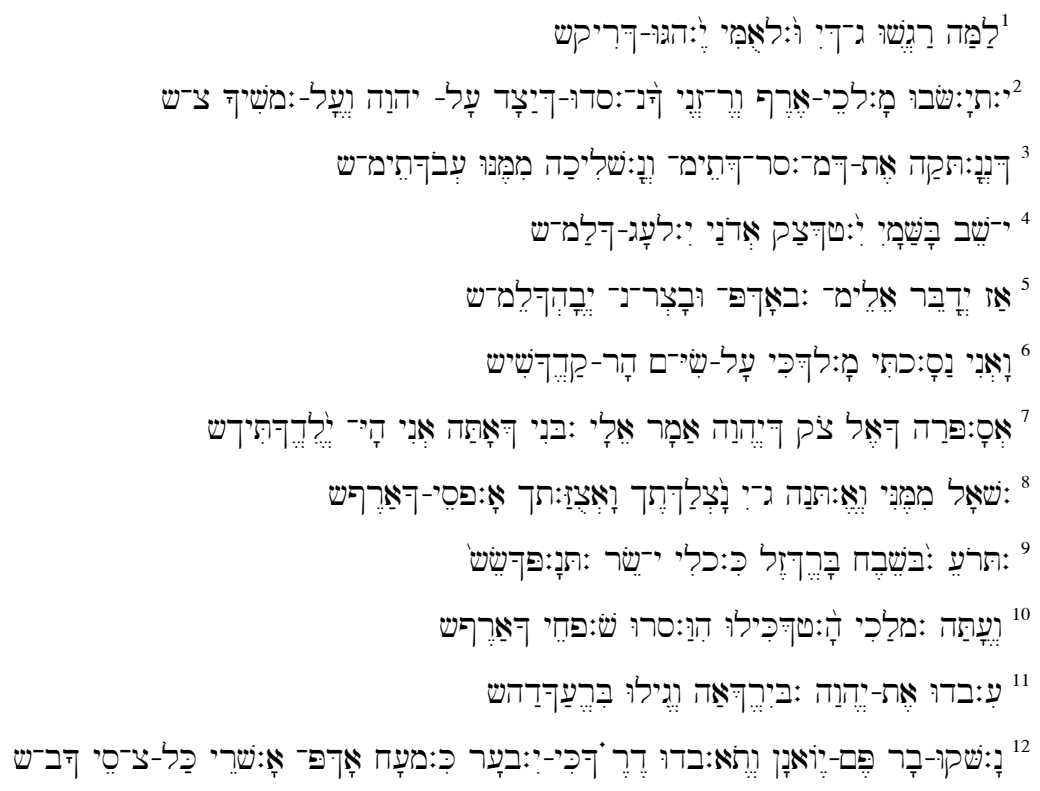

1. Why do the nations are in tumult and people speak vanity?

2. The kings of the earth have taken a stand and the rulers have united together against Yahweh and against his anointed.

3. "Let us tear away their bonds and let us throw away from us their bands".

4. He who dwells in heaven laughs; the Lord mocks at them.

5. At that time, he shall speak to them in his anger and in his burning anger he shall terrify them.

6. "Therefore, I have set my king upon Zion my holy mountain".

7. "I will recount concerning the decree of Yahweh. He said to me": "You are my son, today I have begotten you.

8. Ask from me and I shall give nations as your inheritance and the ends of the earth your possession." 
9. "You shall break them with an iron Scepter you shall shatter them like a potters vessel".

10. Therefore, you kings be considerate, be admonished you rulers of the earth.

11 Serve Yahweh with fear and rejoice with trembling.

12 Kiss the son lest he be angry and you shall perish in the way when he shall be consumed with his little anger; blessed are all who seek refuge in him.

5 STRUCTURAL OUTLINE OF PSALM 2:1-12

1 Nations/kings/rulers rebel against Yahweh and his anointed (2:1-3)

a. Rhetorical question concerning the ground for the commotion/vanity of the nations (v. 1).

b. Kings and rulers of the earth formed a united front against Yahweh/his anointed (v. 2).

c The rebels have plotted to break away from Yahweh's dominion/of his anointed son (v. 3).

2 Yahweh takes measures to counter this rebellion (2:4-9)

a. Yahweh laughs and mocks at the rebels for he controls all powers (v. 4).

b. Yahweh is ready to speak and terrify the rebels (v. 5).

c. Yahweh has set his own king in Zion who shall be obedient to him (v. 6).

d. Yahweh and his son expressed mutual commitment (vv. 7-9).

- Yahweh's son promises to recount Yahweh's decree (v. 7a);

- Yahweh acknowledges the birth of his son (v. 7b);

- Yahweh promises to give the nations of the earth as an inheritance to his son (v. 8);

- Yahweh assures his son of his victory over the nations (v. 9).

3 The Psalmist suggests an alternative way for the rebels (2:10-12)

a. The kings/rulers of the earth should be considerate and wise (v. 10). 
- The rebels should serve Yahweh with fear (v. 11a);

- The rebels should rejoice with trembling (v. 11b);

- The rebels should kiss the feet of Yahweh's son (v. 12a);

b. Failure to heed to the instruction shall result in a disaster for the rebels (v. 12b).

c. Doxology: blessing for all who take refuge in Yahweh's son (v. 12c).

\section{THEOLOGICAL-MYTHOLOGICAL VIEWPOINTS CONCERNING THE SONS OF GOD IN GENESIS 6}

\subsection{Introduction}

I would like to admit from the outset that Genesis 6:1-9 is one of the most difficult and controversial passages in the Old Testament (Walton 2001:291; Buttrick 1952:533; Keck 1994:382). Many questions and issues have been a cause of disagreement among scholars with regard to their interpretation of this passage. The intention of this article is not to deal with all the issues raised by the text. The author is particularly interested in discussing the question: "who are the 'sons of God,' mentioned in Genesis 6?"

The above question is important because it is the first allusion in Genesis to a very important distinction (i.e. the distinction between those who are sons of God and those who are daughters of humankind. This distinction presupposes that there are those who are not sons or daughters of God). Genesis chapters 1-5 discuss the creation of humankind as the work of Yahweh (Gn. 1:26, 27; 2:7, 22; $5: 1,2)$. In view of Yahweh's creatorship, he commanded humankind to multiply and fill the earth (Gn. 1:28). By virtue of being the creator, every human being is a son or daughter of Yahweh.

But, what is particularly puzzling about Genesis 6 is that the author seems to assume that his/her audience knows the distinction between the sons of God and the daughters of men. Because of this presumption, he/she did not elaborate on the identity of the two parties mentioned in the text. The author therefore, has left other readers in suspense.

\subsection{Brief overview of the context of Genesis 6:1-9}

Genesis 6 has been regarded as the summation of the stories in chapters $4 \& 5$ or as an introduction to the flood narrative in chapters 6 to 8 (Walton 2001:290; Wenham 1987:136-137). This means that 
the passage is a summary of the genealogical records of Cananites and Sethites and their moral behaviour. The passage also provides the basis for the event of the flood.

The text is also understood as introducing the origin of the Nephilim (cf Brueggemann 1982:71; Buttrick 1952:533). According to this theory, "the nucleus of this tale is a brief notice of the origin of the Nephilim, a mythical race of giants referred to again in Numbers 13:33" (Buttrick 1952:533).

There is a feeling that this is a story outside the biblical story (cf Walton 2001:298). Therefore, our ability to fill in the details of the story outside the story is limited. As is usually the case, the narrator has only given as much as we need to see the point he is trying to establish. This leads Walton (2001:298) to suggest that if Genesis 3 represents the fall of humankind and Genesis 4 evidences the fall of the family, Genesis 6 addresses the fall of society.

Whatever the scholarly viewpoint about the structure of this passage, Genesis, to my mind, is a book about beginnings. The exact interpretation of the beginnings might vary. But, my conviction is that Genesis 6:1-9 introduces two dimensions of increase: the increase of humans and the increase of evil.

\subsection{Theological-mythological viewpoints concerning the sons of God in Genesis 6}

There are several viewpoints concerning the motif of divine sonship in Genesis 6. The term 'sons of God' is understood as a metaphor that contains several senses. For example, it is used to designate:

"a close relationship to God..., a male child sired by a father..., a kingship term within a particular clan or tribe..., of Israel collectively..., the special relationship that existed between YHWH and Israel involving both election and preservation..., a royal title throughout the Near East... In Israel, the king was regarded as the adopted son of God..., Angelic beings..., the righteous man... because of the moral quality of his life and finally, the son of God is often considered a messianic title in late Second Temple Judaism" (Neusner 1996:596-597).

I will describe some of these viewpoints in what follows.

- Sons of God as nobles, rulers, kings and leaders

First, the motif of the 'sons of God' is understood as a reference to the nobles, rulers or kings (cf Freedman 1987:213). According to 
this viewpoint, the term does not refer to the literal sons of God; rather, it is a reference to the demoralization of kings, nobles, leaders or rulers. These groups of people were derivatively understood in ancient Near Eastern culture as the sons of God (cf Mathews 1996:328 and Freedman 1987:213). For example, in the Ugaritic myth of King Keret (or Kirta), the king is regarded as the son of El (Arnold and Beyer 2002:88-89; cf Mathews 1996:328). According to Otto (2004:131), the conception of kings as the 'sons of God' was in practice among the Egyptian and Assyrian traditions. In view of this background, the Jewish conception of Yahweh's rule through human rulers, kings, magistrates and leaders was not an isolated case. Israel shared the belief that kings, rulers or leaders were appointed by Yahweh to function in his stead. Therefore, Israel perceived itself as a theocratic state, where Yahweh rules through these kings, prophets and priests. Derivatively, these rulers, kings or leaders were regarded as the adopted sons of God.

In adopting this view of the sons of God as kings, it is therefore, suggested that the offense of these sons of God or kings in Genesis 6 was the practice of the 'right of the first night.' In certain ancient Near Eastern societies, the local authority (whether king, governor, or lord of the manor) imposes his will on his people by demanding and exercising the right to spend the first night with any woman who is being married (Walton 2001:293). Another version of the same theory is that the reason why the royal figures were called sons of God in Genesis 6 was that they had lived for a long period, without trouble or suffering, as if they were divine (cf Freedman 1987:213).

But this view of kings as the sons of God is contested by Mathews (1996:329). According to him, the motif of kingship is not reflected in the primeval stories; therefore, it is absurd to regard the sons of God in Genesis 6 as kings or rulers. He argued that there are evidences in the ancient Near Eastern tradition where an individual king or ruler was regarded as a son of God. However, there is no place where groups of kings or rulers were collectively regarded as the sons of God. He also rejects the theory that rape was the sin of these sons of God. He noted that there was no coercion between the sons of God and the daughters of men in Genesis 6.

- Sons of God as angelic beings, spirits, godlike beings, or demons 
Second is the viewpoint that the sons of God refer to angelic beings, spirits, godlike beings, or demons et cetera (Walton 2001:291; Mathews 1996:325-328; Westermann 1984:371; Leupold 1942:251). Other biblical texts are also quoted to support this perspective. Such passages include Job 2:1; 38:7; Daniel 3:25 and Psalm 29:1; 89:7. Yet others consider Jude 6 and 2 Peter 2:4 and 1 Enoch 6-11, as allusions to the angelic beings as sons of God (cf Hamilton 1990:271). This line of argument also points to other examples such as the Ugaritic literature to give impetus to this perspective. For example, the Epic of Gilgamesh portrays Ishtar, a female goddess, proposing marriage to Gilgamesh who is conceived as a semi-god (Mathews 1996:326: cf Arnold and Beyer 2002:70). Therefore, it is pointed out that in the Ugaritic culture, the sons of God refer to the members of the divine pantheon (Wenham 1987:139). Consequently, it is likely that the use of the phrase (the sons of God) in Genesis 6 embodied a similar sense. A grammatical argument is also used to support this view. It is contended that the contrast between 'sons of God' and 'daughters of men' demands that the former be considered as being divine and the latter human (Leupold 1942:251).

But several arguments have been put forward against this notion of 'angels' as sons of God. According to Walton (2001:292), "(1) Cohabitation between angels and humans has no immediate obvious connection with the purpose of Genesis; (2) an angelic intrusion is considered out of place in the sequence of episodes recounting the advance of human sin; and (3) the mythological tone is at odds with life in the real world as we know it." It is also argued that the notion of angels as the sons of God contradicts Jesus' response to the question about marriage in Matthew 22:30 (cf Mathews 1996:326-327). Jesus is quoted to have said angels do not marry. Therefore, it is pointed out that "such an approach introduces the mythological element as well as polytheism into the scriptures and makes the Bible a record of strange and fantastic tales and contradicts Matthew 22:30." In addition, it is contended that the expression used in Genesis 6:2, they took to themselves wives, is the standard expression for marital union. Genesis 6 does not refer to adulterous irregularities but to permanent union (Leupold 1942:253).

Other things to observe about this angelic view are that if the term 'sons of God' refers to angels, this will introduce a twofold fall of angels: the original and this, the second. This will create a whole new phenomenon in the Bible. It will contradict the principle of 
individual responsibility. That means, 'angels sinned', 'men are punished'. Note also that in a parallel case the serpent (fallen angel who disguised himself as a serpent), was punished first (Gn. 3:14, $15)$, then the man and the woman were punished. But in chapter 6 , there is no mention of the punishment of the presupposed angels. Again, this interpretation will also suggest that the women taken were practically innocent (Leupold 1942:253-254).

- Sons of God as the descendants of Seth in opposition to Cain

Third, the 'sons of God' refer to the descendants of Seth excluding those of Cain (Wenham 1987:139; Keck 1994:382; Westermann 1984:371). It is argued that those who descended from the line of Seth (such as Enoch who walked with God; cf Gn 5:22) and Lamech (who publicly worshipped God and confessed his name; cf Gn. 4:26; $5: 29)$ merited the title 'sons of God. This argument points to scriptural passages that contain similar allusions. These include Psalm 73:15; 80:17 Deuteronomy 32:5 (referring to Israel), and Hosea 1:10 (Leupold 1942:250 \& 251; see also Walton 2001:291).

According to Vos (1948:48) the sons of God were the Sethites, while the daughters of men were the Cainites. He noted that God permitted the Sethites to intermarry with the Cainites so that "the lesson of the inherent destructive potencies of sin" will be fully taught. He also pointed out that "If the angel theory be accepted, this will tend to obscure the idea aimed at. In that case we shall have no longer a development of human sin left to itself, but a development under the influence of a quite extraordinary superhuman factor $a b$ exra" (Vos 1948:48).

- $\quad$ Son(s) of God as the Messiah

Fourth, the motif of divine sonship is used during the Second Temple period to refer to the Messiah (Neusner 1996:597). The Qumran document 4Q Florilegium 10-14 and 2 Samuel 7:12-14 are quoted to support the Messianic theory. Similarly, the Messiah is referred to in speeches attributed to God as his son (see 4 Esdras 7:28-29, 13:32, 37, 52; 14:9; 1 Enoch 105:2). Psalm 2 also contains a specific reference to the Messiah as the son of Yahweh. This Messiah is established in Zion by Yahweh as the king who will rule over other earthly kings. Other references from the New Testament that conceive the son of God as the Messiah include Matthew 16:16; 26:63; Mark 14:61-62; Luke 1:32-33, 4:41, 22:66-70; John 1:49, 11:27; Acts 9:20-22. 
The above discussion reveals that there is basically no consensus among scholars concerning the meaning of the term 'sons of God' contained in Genesis 6. I must also confess my ignorance on this subject. Though, if I were to make a choice from the existing viewpoints on the subject, I will opt for the viewpoint that the sons of God were kings, rulers or leaders. The basis for adopting this position is that first, the concept of kings as sons of the gods coheres with the mythological conception of the ancient world from which this text seems to have originated. Second, the intrusion of angelic beings in this passage is unnecessary since the story does not call for such intrusion. Third, the doctrine of individual responsibility will be eliminated if the angelic view is adopted. The punishment wrought on humankind excludes angels, but in Genesis 3 both culprits are punished. Therefore, I adopt the viewpoint that the sons of God in Genesis 6 refer to kings/rulers and leaders.

\section{THEOLOGICAL-MYTHOLOGICAL VIEWPOINTS CONCERNING DIVINE SONSHIP IN PSALM 2}

\subsection{Classification of Psalm 2}

This psalm belongs to a group known as the royal psalms (cf Anderson 1972:63; Kraus 1988:125; Mays 1994:45; Weiser 1962:109). It is self evident that the psalm presents a theology of divine kingship. The limited power of earthly kings/rulers is contrasted sharply with the omnipotent powers of Yahweh and his anointed son/king.

\subsection{Setting/Occasion of the Psalm}

This psalm is believed to be composed for the festival of the coronation or enthronement of a Judaic king (cf Craigie 1983:64-65; Anderson 1972:63). In ancient Orient, the death of a suzerainty king could spark great agitation from the vassal kings (Weiser 1962:109). These vassal kings used such instances to break away from their overlord. Thus, it was absolutely necessary for the new suzerainty king to suppress such agitations in order to restrain the vassal kings from revolting and breaking away from the domineering kingdom.

Similarly, Psalm 2 is thought to have been composed to address similar situations in Israel. There are various theories concerning the identity of the specific king of Judah with reference to whom such a psalm could have been utilized (cf Mays 1994:49; Craigie 1983:64-65; Brown and James 1969: 12; Weiser 1962:109). Kings David, Solomon, Hezekiah and Josiah et cetera have been 
suggested. But it is difficult to name a specific Judaic king whom the psalm could have been applied (Anderson 1972:64)). However, it is likely that the psalm may have been used in the pre-exilic period during the enthronement/coronation festival. This view is however, contested. The opposite view is that the psalm was composed in the post-exilic period. It was a prophetic eschatological song describing the coming of a messianic eschatological king from the line of David (Anderson 1972:64; cf 2 Sm 7:11-16; Jer 23:5; 30:9; Ezk 34:23; $37: 24)$.

\subsection{The anointed son/king of Yahweh}

This section addresses the issue of divine sonship mentioned in Psalm 2. It has already been observed from the above section that the identity of the king with reference to whom this psalm was used in his coronation or enthronement could hardly be ascertained. Therefore, in attempting to address the motif of divine sonship contained in this passage, it is imperative to acknowledge the difficulty of such a task from the outset. But this difficulty should not derail the ability to provide a conjecture concerning the motif of divine sonship.

Psalm 2 begins with the rebellion of the nations/rulers and kings against Yahweh and his anointed son (vv. 1-3). Yahweh counters this rebellion through a number of measures (vv. 4-9). First, Yahweh is not disturbed by this rebellion; rather, he laughs and terrifies the rebels (vv. 4-5). Second, Yahweh anoints his son and sets him in Zion as a king (v. 6). Third, Yahweh and his anointed son describe their mutual commitment (vv. 7-9). The son shall recount Yahweh's decree. Yahweh acknowledges the birth of his son and promises to give his anointed son the power to crush the rebels. In view of the above, the Psalmist warned the rebels to adopt wisdom by serving Yahweh, rejoicing with trembling and kissing the feet of his son (vv. 10-12a). Failure to heed to the above warning will lead these rebels to final disaster (v. 12b). The Psalmist doxologically expresses the universal need to take refuge in Yahweh's son (v. 12c).

Therefore, who is this divine son? When in the history of the Judaic kings did such a king posses the universal authority over other nations? There is basically no Israelite/Judaic king who had such sweeping authority that it extended to the rest of the known world at the time the psalm may have been composed. Therefore, this son of Yahweh cannot be identified with a specific historical 
individual. This difficulty has led scholars to adopt a number of possible interpretations: 1) that this universal reign of the anointed king from Zion was an ideal that could be met in the eschatological period (Anderson 1972:64); and 2) that Israel shared a conviction that Yahweh himself was present at the coronation of every Davidic king - therefore, the universal authority of Yahweh was present through the reigning king of Judah in a metaphorical sense (cf Craigie 1983:65).

These two above viewpoints can enhance/enrich the understanding of this text if taken together. It should be noted that the relationship between Yahweh and his earthly king portrayed as his anointed son is a familiar concept in the Ancient Near Eastern world (Freedman 1987:213). As mentioned in the previous discussion, in the ancient Orient, the relation of a king to the divine pantheon was that of a son. The king was referred to as a divine son (Arnold and Beyer 2002:88-89). Because of this understanding, the subjects were obliged to obey the king. Obedience to the king was considered as obedience to the gods of that nation. Disobedience to the king was perceived as disobedience to the gods. Thus, the motif of divine sonship in Psalm 2 should be understood partly from this background. But in addition to that, the conception of this son of Yahweh as an eschatological king needs to be taken into consideration.

In view of the above, my conviction is that the motif of divine sonship in Psalm 2 contains two dimensions. On the one hand, the concept of the king as the son of Yahweh is an allusion to the mythological conception of a king as the son of God common in the Ancient Near Eastern tradition. On the other hand, Psalm 2 provides an allusion to the eschatological reign of a Davidic king who is also the Messiah. This king will be obedient to Yahweh and his covenant. $\mathrm{He}$ will not be as frail as the rest of the Israelite/Judaic kings recorded in the Old Testament. His reign will take place at the end of the age as alluded to in some other biblical/extra-biblical texts ${ }^{4}$.

4 Cf Jr 31:31-39; 4 Esdras 7:28-29, 13:32, 37, 52; 14:9; 1 Enoch 105:2; Mt 16:16; 26:63; Mk 14:61-62; Lk 1:32-33, 4:41, 22:66-70; Jn 1:49, 11:27; Ac $9: 20-22$. 


\section{SIMILARITIES AND DIFFERENCES BETWEEN GENESIS 6 AND PSALM 2}

\subsection{Similarities between Genesis 6 and Psalm 2}

1. Perpetrators of rebellion against Yahweh are the kings/rulers in both texts. If it is accepted that the sons of God mentioned in Genesis 6 are rulers/kings or leaders, then, their attitude in Genesis 6 is directed against Yahweh's will for his sons just as the attitude of the kings of the earth in Psalm 2 is directed against Yahweh's will for his anointed son.

2. In both texts, there is a union of some kind between the perpetrators of evil. In Genesis 6, the union is an evil marital relationship. In Psalm 2, the union is not a marital one but it is done with an evil intention.

3. The unruly attitude of the Nephilim in Genesis 6 is similar to the plot of the rulers/kings to break away from the dominion of Yahweh and his son in Psalm 2.

4. Yahweh adopts measures to suppress the rebellion of the rulers/kings in both texts. Yahweh cut short the life-span of humankind and plans to destroy them in the flood in Genesis 6; while in Psalm 2, Yahweh gives authority to his anointed son to crush the rebellion.

5. Yahweh finds one individual among humankind who is obedient to him and who will execute his plans in both texts. In Genesis 6, Yahweh finds Noah who remained obedient to him despite the rebellion of other people. In Psalm 2, Yahweh finds his anointed son who is obedient to him and will execute his plan.

\subsection{Differences between Genesis 6 and Psalm 2}

1. The sons of God in Genesis 6 are many, while there is one divine son only in Psalm 2.

2. Yahweh is the indirect object of the rebellion in Genesis 6; while in Psalm 2, Yahweh and his anointed son are the direct objects of the rebellion of the kings/rulers.

3. If the motif of the 'sons of God' in Genesis 6 is understood in a literal sense, then the sons of God here are disobedient to Yahweh. But in Psalm 2, the son of God is obedient to Yahweh. 
4. The motif of eschatological divine sonship is implicitly contained in Psalm 2 where as, the concept is not detected in the text of Genesis 6.

\subsection{CONCLUSION}

This article has described the theological and mythological scholarly viewpoints concerning the motif of divine sonship in Genesis 6:1-9 and Psalm 2:1-12. The author has adopted the position that the sons of God in Genesis 6 refer to the kings, rulers and leaders in the primeval time. He also pointed out certain similarities and differences between the two texts. He contended that the motif of divine sonship in Genesis 6 differs in a certain sense from that of Psalm 2. One of the reasons for this difference is that the eschatological expectation of the reign of the Son of God seems to lie behind the text of Psalm 2, whereas, in Genesis 6, it does not. Therefore, these two biblical texts may best be understood against the backdrop of the Ancient Near Eastern conception of the kings as sons of the gods. But in addition to that, Psalm 2 may also be viewed as an eschatological psalm, depicting the future reign of a Davidic king who is also the Messiah. This king will not be frail as the previous Israelite/Judaic kings. Rather, he will be obedient to Yahweh. All other kings and rulers of the earth will have to submit to the authority of this Messianic king in order to escape his final wrath.

\section{Consulted literature}

Anderson, A A 1972. The Book of Psalms. London: Marshall, Morgan and Scott (New Century Bible).

Arnold, B T \& Beyer, B E (eds.) 2002. Readings from the Ancient Near East: Primary Sources for Old Testament Study. Grand Rapids: Baker.

Batto, B F 1992. Slaying the Dragon: Mythmaking in the Biblical Tradition. Louisville: Westminster/John Knox Press.

Brueggemann, W 1982. Genesis: A Bible Commentary for Teaching and Preaching. Atlanta: John Knox Press (Interpretation).

Buttrick, G A 1952. The Interpreter's Bible Vol. 1. New York: Abingdon Cokesbury Press.

Calvin, J 5a. Commentaries on the First Book of Moses Called Genesis. Vol. 1. Grand Rapids: Baker Book House.

Coats, G W 1983. Genesis with an Introduction to Narrative Literature. Grand Rapids: Eerdmans (Forms of Old Testament Literature Series1). 
Craigie, P C 1983. Psalm 1-50. Word Biblical Commentary Vol. 19. Waco: Word Books, Publishers.

Freedman, H 1987. Rabbah: Genesis Vol.1. London: The Soncino Press.

Gottlieb, H 1980. "Myth in the Psalms", in Otzen, B, Gottlieb, H \& Jeppesen, K (eds.). Myths in the Old Testament. Translated by Cryer, F London: SCM.

Hamilton, V P 1990. The Book of Genesis :Chapters 1-17. Grand Rapids: William B. Eerdmans Publishing Company.

Keck, L E 1994. The New Interpreter's Bible Vol. 1. Nashville: Abingdon Press.

Keil, C F \& Delitzsch, F 1973. Commentary on the Old Testament in Ten Volumes: Vol. V: Psalms. Translated by Martin, J. Grand Rapids: Eerdmans.

Kraus, H J 1988. Psalms 1-59: A Commentary. Translated by Oswald, H C. Minneapolis: Augsburg Publishing House.

Leupold, H C 1942. Exposition of Genesis Vol. 1: Chapters 1-19. Grand Rapids: Baker Book House.

Mathews, K A 1996. The New American Commentary: An Exegetical and Theological Exposition of Holy Scripture Vol.1A: Genesis. Nashville: Broadman \& Holman Publishers.

Mays, J L 1994. Psalms: A Biblical Commentary for Teaching and Preaching. Louisville: John Knox Press (Interpretation).

Neusner, J 1996. Dictionary of Judaism in the Biblical period Vol. 2. New York: Simon \& Schuster Macmillan.

Otzen, B, Gottlieb, H \& Jeppesen, K 1980. Myths in the Old Testament. Translated by Cryer, F. London: SCM.

Otzen, B 1980. "The Use of Myth in Genesis", in Otzen, B, Gottlieb, H \& Jeppesen, K (eds.). Myths in the Old Testament. Translated by Cryer, F. London: SCM Press Ltd.

Plumer, W S 1975. Psalms: A Critical and Expository Commentary with Doctrinal and Practical Remarks. Edinburgh: The Banner of Truth Trust.

Vos, G 1948. Biblical Theology: Old and New Testaments. Edinburgh: The banner of Truth Trust.

Walton, J H 2001. Genesis: The NIV Application Commentary. Grand Rapids: Zondervan.

Wenham, G J 1987. Genesis 1-15. Word Biblical Commentary Vol. 1. Waco: Word Books, Publisher.

Weiser, A 1962. The Psalms: A Commentary. Translated by Hartwell, $\mathrm{H}$. London: SCM (Old Testament Library).

Westermann, C 1984. Genesis 1-11: A Commentary. Translated by Scullion, J J. London: SPCK. 